\title{
Graphene-beaded carbon nanofibers with incorporated Ni nanoparticles as efficient counter electrode for dye-sensitized solar cells
}

\author{
Zhengping Zhou ${ }^{\mathrm{a}, \mathrm{b}, \uparrow}$, Sudhan Sigdel $^{\mathrm{a}, \uparrow}$, Jiawei Gong, ${ }^{\mathrm{a}, \mathrm{b}}$, Bjorn Vaagensmith ${ }^{\mathrm{a}}$, Hytham Elbohy ${ }^{\mathrm{a}}$, Huojun \\ Yang $^{\mathrm{c}}$, Sumathy Krishnan ${ }^{\mathrm{b}}$, Xiang-Fa Wu ${ }^{* \mathrm{~b}}$ and Qiquan Qiao ${ }^{{ }^{\mathrm{a}}}$ \\ ${ }^{a}$ Center for Advanced Photovoltaics, Department of Electrical Engineering and Computer Sciences, South Dakota State University, Brookings, SD, 57007, \\ USA.Tel:1-605-688-6965; Fax: 1-605-688-4401; Email:Qiquan.Qiao@sdstate.edu \\ ${ }^{b}$ Department of Mechanical Engineering, North Dakota State University, Fargo, ND 58108, USA. Tel: 1-701-231-8836; Fax: 1-701-231-8913; \\ E-mail: xiangfa.wu@ndsu.edu \\ ${ }^{c}$ Department of Construction Management and Engineering, North Dakota State University, Fargo, ND 58108, USA. \\ $\dagger$ These authors contributed equally to this work.
}

A novel porous three dimensional (3D) hierarchical graphene-beaded carbon nanofibers with incorporated $\mathrm{Ni}$ nanoparticles (G/CNFs-Ni) were used for the first time as cost-effective counter electrode for dye-sensitized solar cells (DSCs). G/CNFs-Ni was synthesized by electrospinning G/PAN/Ni(AcAc)2 precursor nanofibers, followed by carbonization and activation. The introduction of graphene nanosheets and Ni nanoparticles in CNF networks significantly increased the cells' stability and decreased the charge-transfer resistance at the interface between electrolyte and counter electrode, leading to the high electrocatalytic activity/efficiency for triiodide reduction. The G/CNFs-Ni composite counter electrodes possessed larger capacitance than that of Pt counter electrodes due to larger specific surface area, leading to significantly higher electrocatalytic activity/efficiency for triiodide reduction at the interface between electrolyte and counter electrode. The dye-sensitized solar cells (DSCs) fabricated using G/CNF-Ni composite as counter electrodes were tested at $100 \mathrm{~mW} / \mathrm{cm}^{2}$ AM 1.5 illumination. The G/CNFs-Ni composite exhibited an overall power conversion efficiency of $7.14 \%$ as compared to $7.59 \%$ for reference platinum $(\mathrm{Pt})$ counter electrodes.

\section{Introduction}

As one of the third-generation photovoltaic devices, dye-sensitized solar cells (DSCs) have received extensive attention as a prospective alternative to conventional silicon solar cells due to their low production cost, ease of fabrication and high power conversion efficiency (up to $13 \%$ ) $^{1-5}$. In addition, DSCs can offer numerous versatile properties such as transparency with tunable colors, mechanical flexibility, and are less likely to reduce power conversion efficiency in faint light and at high temperature ${ }^{4-7}$. Typically, a DSC is composed of three primary components: photoanode, counter electrode and electrolyte. The photoanode is typically a dye-adsorbed nanoporous titanium dioxide $\left(\mathrm{TiO}_{2}\right)$ layer deposited on a fluorine-doped tin oxide (FTO) conductive glass substrate. The most commonly used counter electrode in DSCs is a platinum $(\mathrm{Pt})$-coated FTO glass substrate. The electrolyte containing an iodide/triiodide $\left(\mathrm{I}^{-} / \mathrm{I}_{3}{ }^{-}\right)$ redox couple fills the gap between the photoanode and counter electrode. When the adsorbed dye molecule absorb sunlight, photoelectrons will be generated and then rapidly injected into the conductive layer of mesoporous photoanode. The injected electrons diffuses across the photoanode to be collected, and then passed through an external circuit to complete a current cycle in DSCs ${ }^{8-11}$.

Platinum nanoparticles have high electrocatalytic activity toward $\mathrm{I}_{3}{ }^{-}$reduction and excellent electrical conductivity ${ }^{12,}{ }^{13}$. However, Pt is a high-cost noble metal and its widespread use in industrial-scale applications has been limited. In order to develop cost-effective DSCs, considerable efforts have been performed to replace $\mathrm{Pt}$ with cheaper and earth-abundant carbonaceous materials such as activated carbon, carbon nanotubes (CNTs), electrospun carbon nanofibers (ECNFs), and graphene ${ }^{14-18}$. It is noteworthy that these carbon-based nanomaterials have high surface area, excellent conductivity, and controllable porous morphology, leading to a large number of electrocatalytic sites toward reduction of $\mathrm{I}_{3}^{-}$.

In our previous work ${ }^{15,19,20}$, we prepared $\mathrm{Ni}$ nanoparticles incorporated carbon nanotube/nanofiber composite (Ni-CNT-CNF) as cost-effective electrode in DSCs and supercapacitors using electrospun polyacrylonitrile (PAN) and nickel acetylacetonate $\left[\mathrm{Ni}(\mathrm{AcAc})_{2}\right]$ nanofibers and controlled carbonization and CNT growth. The unique Ni-CNT-CNF composite has been demonstrated as an efficient electrocatalytic counter electrode material with lower charge transfer resistance $\left(R_{c t}\right)$, larger surface area, and faster reaction rate for reduction of the $\mathrm{I}^{-} / \mathrm{I}_{3}{ }^{-}$redox couple than that of the conventional Pt counter electrode.

In this work, we have developed another new cost-effective counter electrode based on hierarchical graphene nanosheet -beaded carbon nanofibers with incorporated $\mathrm{Ni}$ nanoparticles (G/CNFs-Ni). To the best of our knowledge, this new counter electrode composite has not been reported previously. G/CNFs-Ni composite was synthesized by electrospinning PAN/N,N-dimethylformamide (DMF) solution dispersed with 
graphene nanosheets and $\mathrm{Ni}(\mathrm{AcAc})_{2}$, followed by controlled oxidation and carbonization. The G/CNFs-Ni composite counter electrodes possessed larger capacitance than that of $\mathrm{Pt}$ counter electrodes due to larger specific surface area, leading to significantly higher electrocatalytic activity/efficiency for triiodide reduction at the interface between electrolyte and counter electrode. Previous work showed that pure $\mathrm{CNF}^{16}$, pure graphene $^{11}$, and $\mathrm{C} / \mathrm{Ni}$ nanoparticles ${ }^{21}$ had much lower efficiency than Pt counter electrode. This motivated us to use CNF to embed and connect graphene nanosheet together and attach $\mathrm{Ni}$ nanoparticles on the surface of both CNF and graphene nanosheet to grow more carbon nano-cladding in order to both increase surface area and also increase counter electrode stability. The experimental results indicated that the G/CNFs-Ni composite counter electrode based DSCs had excellent electrocatalytic performance with lower charge transfer resistance $\left(R_{c t}\right)$, and larger open circuit voltage $\left(V_{o c}\right)$ as well as higher stability in the reduction of triiodide ions as that of the conventional Pt counter electrode.

\section{Experimental}

\section{Preparation of G/CNFs-Ni mat}

Prior to electrospinning, a hybrid suspension containing Polyacrylonitrile (PAN, Mw=150,000), graphene nanosheets (M-25, specific surface area: $120-150 \mathrm{~m}^{2} / \mathrm{g}$ ) and Nickel acetylacetonate $\left[\mathrm{Ni}(\mathrm{AcAc})_{2}\right]$ was prepared using the following route. $1 \mathrm{~g}$ PAN powder and $0.2 \mathrm{~g}$ graphene nanosheets were first added into $9 \mathrm{~g} \mathrm{~N}, \mathrm{~N}$-dimethylformamide (DMF) to prepare a graphene/PAN (G/PAN, mass ratio=1:5) suspension at a temperature of $80{ }^{\circ} \mathrm{C}$ with continuous stirring for $24 \mathrm{~h} .0 .6 \mathrm{~g}$ $\mathrm{Ni}(\mathrm{AcAc})_{2}$ was then added into the G/PAN suspension and stirred for $6 \mathrm{~h}$ to form an electrospinnable hybrid suspension of $\mathrm{G} / \mathrm{PAN} / \mathrm{Ni}(\mathrm{AcAc})_{2}($ mass ratio=1:5:3) at room temperature. The concentrations of PAN, graphene nanosheets and $\mathrm{Ni}(\mathrm{AcAc})_{2}$ in the resulting suspension were 9.26 wt. $\%, 1.85$ wt. $\%$ and 5.56 wt. $\%$, respectively. The above suspension was then filled into a $10-\mathrm{ml}$ plastic syringe installed with a stainless-steel needle. This needle was connected to a high-voltage DC power supply (Gamma High Voltage Research, Inc., Ormond Beach, FL). During the electrospinning, the solution was performed in a high DC electrical field of $80 \mathrm{kV} / \mathrm{m}$. This high electrical field was generated by applying a positive voltage of $20 \mathrm{kV}$ to a $25 \mathrm{~cm}$ gap between the tip of the needle and a grounded fiber collector. The precursor nanofibers were collected on a laboratory-made rotary aluminum disk with a diameter of $33 \mathrm{~cm}$. The flow rate was maintained at $1.0 \mathrm{ml} / \mathrm{h}$. Subsequently, the electrospun $\mathrm{G} / \mathrm{PAN} / \mathrm{Ni}(\mathrm{AcAc})_{2}$ nanofiber mat was peeled off from the fiber collector and dried in a vacuum oven at $100{ }^{\circ} \mathrm{C}$ for $6 \mathrm{~h}$.

The oxidation, carbonization and activation of electrospun $\mathrm{G} / \mathrm{PAN} / \mathrm{Ni}(\mathrm{AcAc})_{2}$ nanofibers were performed by the following procedures in a tubular quartz furnace. Briefly, the nanofibers were first heated up at a slow heating rate of $1{ }^{\circ} \mathrm{C} / \mathrm{min}$ and annealed at $210^{\circ} \mathrm{C}$ for $1 \mathrm{~h}$ in air for the oxidative stabilization of PAN nanofibers. The stabilized nanofibers were then carbonized as the temperature was ramped from 210 to $800{ }^{\circ} \mathrm{C}$ at $5^{\circ} \mathrm{C} / \mathrm{min}$, with a constant argon (Ar) flow of $200 \mathrm{sccm}$, followed by annealing at $800{ }^{\circ} \mathrm{C}$ for $30 \mathrm{~min}$ to grow $\mathrm{Ni}$ nanoparticles.
Thereafter, the furnace was naturally cooled down to $400{ }^{\circ} \mathrm{C}$ in $\mathrm{Ar}$ and then annealed at $400{ }^{\circ} \mathrm{C}$ by introducing air for $1 \mathrm{~h}$ for activation of the carbonized nanofibers.

\section{Fabrication of counter electrodes}

For electrodes used in DSCs, CV and EIS, G/CNFs-Ni counter electrodes were prepared by the following procedures. The $\mathrm{G} / \mathrm{CNFs}-\mathrm{Ni}$ mat $(0.01 \mathrm{~g})$ was first crushed and then mixed with $0.001 \mathrm{~g} \mathrm{TiO}_{2}$ (Degussa P25) in $4 \mathrm{ml}$ ethanol, followed by sonication for $30 \mathrm{~min}$. The resulting suspension was then spray coated onto a cleaned FTO-glass substrate. The coated substrate was annealed at $60{ }^{\circ} \mathrm{C}$ for $12 \mathrm{~h}$ in air. The average thickness of the coated G/CNFs-Ni films was approximately $10 \mu \mathrm{m}$. Note that the coating thickness can be adjusted by the spraying duration. In principle, primary factors for counter electrodes affect the DSC performance include the electrical conductivity and electrocatalytic activity for the reduction of $\mathrm{I}^{-} / \mathrm{I}_{3}{ }^{-}$redox couple. Therefore, the thickness effect of counter electrodes on DSC performance has not been investigated in this study. For comparison, a Pt counter electrode with a thickness of $\sim 40 \mathrm{~nm}$ was prepared by spin coating a Pt precursor solution $(0.02 \mathrm{M}$ $\mathrm{H}_{2} \mathrm{PtCl}_{6} \cdot 6 \mathrm{H}_{2} \mathrm{O}$ in anhydrous ethanol) at $3000 \mathrm{rpm}$ for $20 \mathrm{~s}$, and heating it at $400{ }^{\circ} \mathrm{C}$ for $15 \mathrm{~min}$ in air. Moreover, the thickness of Pt coating can be varied by spinning rate and duration.

\section{Assembly of DSCs}

For the preparation of a photoanode, a cleaned FTO-glass substrate was first treated in $40 \mathrm{mM}$ of $\mathrm{TiCl}_{4}$ aqueous solution at $70{ }^{\circ} \mathrm{C}$ for $30 \mathrm{~min}$ and the $\mathrm{TiO}_{2}$ compact layer was then spin coated on top of it. The nanocrystalline $\mathrm{TiO}_{2}$ layer (Solaronix Ti-Nanoxide HT/SP, 12-13 $\mu \mathrm{m}$ thick) and light scattering layer (Solaronix Ti-Nanooxide R/SP, 4-5 $\mu \mathrm{m}$ thick) were then deposited by doctor blading, respectively. Subsequently, it was treated in $40 \mathrm{mM}$ of $\mathrm{TiCl}_{4}$ aqueous solution at $80{ }^{\circ} \mathrm{C}$ for $30 \mathrm{~min}$. After depositing each layer mentioned above, the anode was sintered at $475{ }^{\circ} \mathrm{C}$ for $40 \mathrm{~min}$. Finally, it was immersed in a solution of $0.3 \mathrm{mM}$ Ruthenizer 535-bisTBA dye (Solaronix $\mathrm{N}-719$ ) in acetonitrile/t-butanol (volume ratio: 1:1) for $24 \mathrm{~h}$ at room temperature. Thereafter, the anode was rinsed in acetonitrile to remove excess dye and then dried in air.

To assemble DSCs, $0.03 \mathrm{M}$ iodine $\left(\mathrm{I}_{2}\right), \quad 0.6 \mathrm{M}$ 1-butyl-3-methylimidazolium iodide (BMII), $0.1 \mathrm{M}$ guanidine thiocyanate (GuSCN) and $0.5 \mathrm{M}$ tert-butylpyridin (TBP) were dissolved in a mixture solvent of acetonitrile and valeronitrile (85:15 by volume) to form a $\mathrm{I}^{-} / \mathrm{I}_{3}{ }^{-}$electrolyte solution. The photoanode was assembled with each of the prepared counter electrodes using a thermoplastic sealant. The $\mathrm{I}^{-} / \mathrm{I}_{3}{ }^{-}$electrolyte was then injected through the reserved channel in between the sealed photoanode and the counter electrode.

\section{Characterization}

The surface morphology and structural property of G/CNFs-Ni were carried out using a high-resolution field-emission scanning electron microscope (SEM, JEOL JSM-7600F) and a transimision electron microscope (TEM, JEOL JEM-200). The computer-controlled Ametek VERSASTAT3-200 potentiostat was used to characterize the cyclic voltammetry (CV) measurement of the resulting counter electrodes. A Pt wire and an $\mathrm{Ag} / \mathrm{AgCl}$ were used as the counter electrode and the reference 
electrode, respectively. The resulting G/CNFs-Ni (or Pt) coated FTO-glass substrate was used as the working electrode. The CV measurement was performed at the potential range of $-0.2-1.2 \mathrm{~V}$ with the scan rate of $50 \mathrm{mV} / \mathrm{s}$ in an acetonitrile solution $\begin{array}{llllllllll}\text { containing } & 10 & \mathrm{mM} & \text { LiI, } & 0.5 & \mathrm{mM} & \mathrm{I}_{2} & \text { and } & 0.1 & \mathrm{M}\end{array}$ tetra-n-butylammonium tetrafluoroborate. The electrochemical impedance spectroscopy (EIS) measurements were performed using the same potentiostat with a frequency analysis module (FDA). The AC signal had the amplitude of $10 \mathrm{mV}$ in the frequency range from $0.1 \mathrm{~Hz}$ to $100 \mathrm{KHz}$ at $0.8 \mathrm{~V}\left(\sim V_{o c}\right) \mathrm{DC}$ bias under dark condition. The current density versus voltage $(J-V)$ characteristics of the devices were tested under AM 1.5 illumination (Xenon lamp, Newport 67005) at a light intensity of $100 \mathrm{~mW} / \mathrm{cm}^{2}$. Same light source coupled with a monochromator and trans-impedance amplifier was used for incident photon-to-current conversion efficiency (IPCE) measurements.

\section{Results and discussions}

The SEM image in Fig. 1(A) shows the representative morphology of the electrospun G/CNFs-Ni mat at low magnification. The nanofiber regions with no visible graphene nanosheets in the G/CNFs-Ni mat carried very rough surface and had uniform diameters ranging from 200 to $300 \mathrm{~nm}$. From Fig. 1(B) at relative high magnification, graphene nanosheets with in planar size of 1-5 microns and thickness of 6-8 nm were closely jointed to CNF segments ${ }^{22}$, while Ni nanoparticles with diameter ranging from of 50-80 nm were randomly distributed on both graphene nanosheets and CNFs ${ }^{19}$. The presence of the $\mathrm{C}, \mathrm{O}$ and $\mathrm{Ni}$ elements from G/CNFs-Ni was verified by energy dispersive X-ray spectroscopy (EDS) as displayed in the inset of Fig. 1(B). Fig. 1(C) and (D) show the mapping images acquired from EDS of $\mathrm{C}$ and $\mathrm{Ni}$ in the G/CNFs-Ni composite counter electrode, respectively. The yellow regions represented carbon nanofibers and graphene nanosheets in the G/CNFs-Ni composite; while the green were from $\mathrm{Ni}$ nanoparticles. $\mathrm{Ni}$ nanoparticles dispersed uniformly within and on the surface of G/CNFs. The percentage concentrations by weight were shown in Table 1 . The G/CNFs-Ni composite had the concentrations of $\mathrm{C}$ and $\mathrm{Ni}$ at $67.26 \mathrm{wt} . \%$ and 30.1 wt. $\%$, respectively. The small amount of $\mathrm{O}$ was from the oxidation and activation processes of precursor nanofibers. In addition, the loading of $\mathrm{Ni}$ nanoparticles can be adjusted by adding $\mathrm{Ni}(\mathrm{AcAc})_{2}$ into the precursor solution.

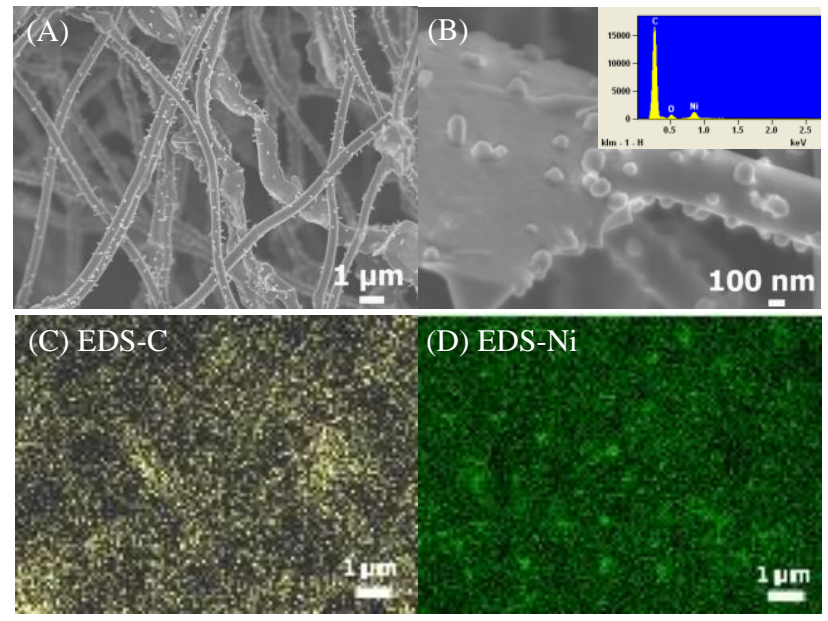

Fig. 1 Top view SEM images of G/CNFs-Ni mat at (A) low and (B) high magnification, respectively; Energy dispersive X-ray spectroscopy (EDS) spectrum [inset of (B)]; Energy dispersive X-ray spectroscopy (EDS) mapping images of (C) $\mathrm{C}$, and (D) Ni in the G/CNFs-Ni composite counter electrode.

Table 1 Percentage concentrations of $\mathrm{C}, \mathrm{O}$, and $\mathrm{Ni}$ by weight in G/CNFs-Ni mat.

\begin{tabular}{ccccc}
\hline Element & Line & $\begin{array}{c}\text { Error } \\
\text { 3-sig }\end{array}$ & Concentration & Units \\
\hline $\mathrm{C}$ & $\mathrm{K} \alpha$ & 0.62 & 67.26 & wt.\% \\
\hline $\mathrm{O}$ & $\mathrm{K} \alpha$ & 0.41 & 2.65 & wt.\% \\
\hline $\mathrm{Ni}$ & $\mathrm{L} \alpha$ & 1.65 & 30.10 & wt.\% \\
\hline
\end{tabular}

The representative TEM images of G/CNFs-Ni after carbonization and activation are shown in Fig. 2. The graphene nanosheets were firmly beaded by the CNF segments, as shown in Fig. 2(A). The beaded graphene nanosheets exhibited a significantly larger diameter than that of nanofiber regions. As indicated in our previous reports, there exists strong linkage between graphene nanosheets and CNFs due to the covalent C-C bonds ${ }^{22,23}$. At the carbonization step, $\mathrm{Ni}(\mathrm{AcAc})_{2}$ was reduced into element $\mathrm{Ni}$ and then aggregated to form $\mathrm{Ni}$ nanoparticles in or on the surface of G/CNFs, as shown in Fig. 2(B). The $\mathrm{Ni}$ nanoparticles in G/CNFs-Ni composite based DSCs might not only promote the electron transfer between the counter electrodes and the redox pairs but also improve the stability in the counter electrode. Closer examination of these black regions (Fig. 2C) revealed that $\mathrm{Ni}$ nanoparticles with sizes of $\sim 5-10 \mathrm{~nm}$ were embedded firmly within the G/CNF framework. From Fig. 2(D), some $\mathrm{Ni}$ nanoparticles grew up to the size of $50-80 \mathrm{~nm}$ and all located on the carbon surface. The function of Ni nanoparticles is to grow carbon nano-claddings ${ }^{24}$ of the surface of both CNF and graphene nanosheets. It is obviously that all $\mathrm{Ni}$ nanoparticles (white arrows) were covered firmly by carbon nano-cladding (black arrows) ${ }^{24}$ in Fig 2 (C) and (D), which might lead to high surface area and numerous electrocatalytic sites toward reduction of $\mathrm{I}_{3}^{-}$.

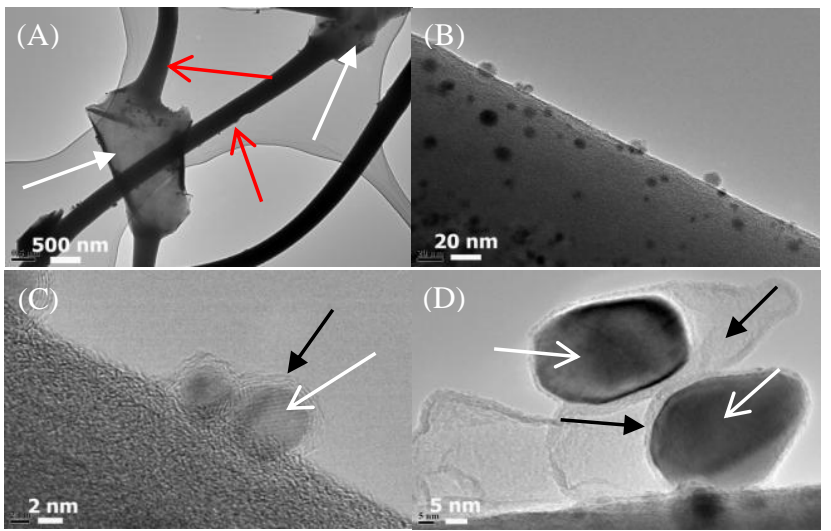

Fig. 2 TEM images of (A) G/CNFs-Ni segments and (B) a typical single CNF surface-grown with Ni nanoparticles; (C) and (D) high magnification TEM images of variation of the size of Ni nanoparticles in or on the surface of a single CNF. The red and white arrows in image (A) mark the CNF segments and graphene nanosheets, respectively; the white arrows in images (C) and (D) indicate the Ni nanoparticles and the black arrows show carbon nano-claddings.

Cyclic voltammetry (CV) is a powerful and efficient method of 
analysing the catalytic mechanisms that occur in an electrochemical system. Fig. 3(A) shows CV results obtained from $\mathrm{Pt}$ and $\mathrm{G} / \mathrm{CNF}-\mathrm{Ni}$ composite counter electrodes in an acetonitrile solution with a scan rate of $50 \mathrm{mV} / \mathrm{s}$ at $2^{\text {nd }}$ cycle. This acetonitrile solution contains $10 \mathrm{mM} \mathrm{LiI}, 0.5 \mathrm{mM} \mathrm{I}_{2}$, and $0.1 \mathrm{M}$ tetra-n-butylammonium tetrafluoroborate as supporting electrolyte and $\mathrm{Ag} / \mathrm{Agcl}$ worked as reference electrode. The pair of oxidation and reduction peaks on the left affect device performance in DSCs. These peaks are directly related to the redox reaction $\mathrm{I}_{3}{ }^{-}+2 \mathrm{e}^{-} \rightarrow 3 \mathrm{I}^{-}$. The G/CNFs-Ni composite counter electrode had both larger oxidation and reduction current densities than those of $\mathrm{Pt}$ counter electrode. These higher peaks demonstrated a faster reduction of triiodide ions by the G/CNFs-Ni composite counter electrode, due to high interfacial surface area and high concentration of defects ${ }^{25}$. In addition to the peak current densities, the peak potential separation of the redox peaks is another factor to characterize the electrocatalytic activity of counter electrode. The standard electrochemical rate constant of a redox reaction is negatively correlated with the peak to peak separation $\left(\mathrm{E}_{\mathrm{pp}}\right)$. For G/CNF-Ni and $\mathrm{Pt}$ counter electrodes, $\mathrm{E}_{\mathrm{pp}}$ values were measured to be 40 and $50 \mathrm{mV}$, respectively. Therefore, the $\mathrm{G} / \mathrm{CNF}$ is more catalytic toward the reaction due to a lower $\mathrm{E}_{\mathrm{pp}}$. Therefore, the G/CNFs-Ni composite can be used as a highly efficient electrocatalytic counter electrode to replace Pt in DSCs.
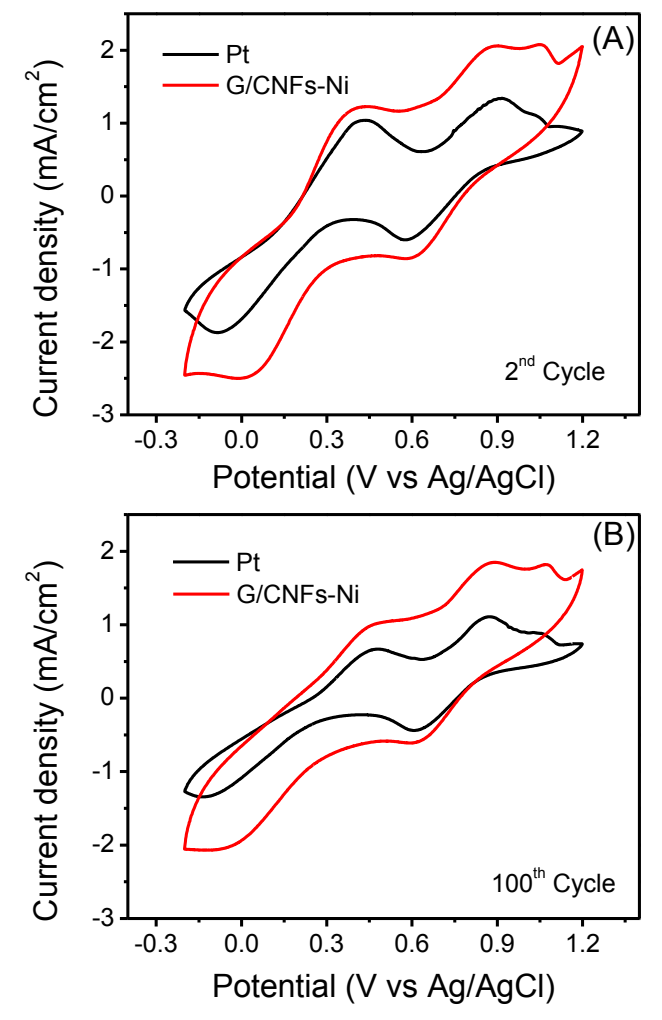

Fig. 3 Cyclic Voltammograms of reference Pt and G/CNFs-Ni composite counter electrodes at $2^{\text {nd }}(A)$ and $100^{\text {th }}(B)$ cycle, respectively.

Fig. 3(B) shows CV curves of $\mathrm{Pt}$ and G/CNFs-Ni counter electrodes at $100^{\text {th }}$ cycle. At $100^{\text {th }}$ cycle, it was observed that the decrease in oxidation and reduction current density (left peaks) was larger in $\mathrm{Pt}$ than in G/CNFs-Ni composite. Also, the area under the curves did not change significantly using G/CNFs-Ni composite, unlike using Pt. These observations indicate that the G/CNFs-Ni composite counter electrode is more stable than $\mathrm{Pt}$ for the redox reaction of the triiodide electrolyte. The improvement in performance for the G/CNFs-Ni composite counter electrode was mainly attributed to the rigid $3 \mathrm{D}$ hierarchical graphene-beaded nanostructures and the incorporated $\mathrm{Ni}$ nanoparticles. The incorporated Ni nanoparticles with carbon nano-claddings in G/CNFs-Ni composite enhanced the contact with a large number of electrocatalytic sites to improve the counter electrode stability ${ }^{25}$. In addition, the graphene-beaded carbon nanofibers have a very unique morphology to combine the advantages from both electrospun CNFs and graphene nanosheets. The CNFs have advantages of being continuity and graphene nanosheets have advantages of large specific surface area and high electrical conductivity. The CNFs also help to connect all the graphene nanosheets together in the counter electrode.

The electrocatalytic performance of the as-prepared counter electrodes was further evaluated by electrochemical impedance spectroscopy (EIS). To eliminate the influence of photoanode, the symmetrical dummy cells were made with two identical Pt or G/CNFs-Ni composite deposited onto FTO-glass substrates and measured from $100 \mathrm{kHz}$ to $0.1 \mathrm{~Hz}$ with an amplitude of $10 \mathrm{mV}$ under dark condition. Fig. 4(A) shows the Nyquist plots of Pt and G/CNFs-Ni composite counter electrodes. Z' and Z" are the real and imaginary parts of the impedance, respectively. An equivalent circuit has also been applied to interpret the measurements performed on the above counter electrodes as shown in Fig. 4(B), where $R_{s}$ is the ohmic series resistance, $R_{c t}$ is the charge transfer resistance on the electrode-electrolyte interface, $Z_{w}$ is the Nernst diffusion impedance of the $\mathrm{I}^{-} / \mathrm{I}_{3}{ }^{-}$redox couple in the electrolyte solution, and CPE is the constant phase element describing the capacitance of the counter electrode $26,27$. The semicircle at high-frequency was resulted from the charge transfer process at the counter electrode-electrolyte interface. The $R_{s}$ in the equivalent circuit corresponds to the overall series resistance, which is calculated by the high-frequency intercept of the semicircle on the real axis. The $R_{s}$ and $R_{c t}$ results were extracted from fitting the Nyquist plots as shown in Table 2. The $R_{c t}$ of the G/CNFs-Ni composite electrode was $0.72 \Omega \cdot \mathrm{cm}^{2}$ compared to $1.30 \Omega \cdot \mathrm{cm}^{2}$ from the Pt electrode. The smaller $R_{c t}$ of the G/CNFs-Ni composite electrode implies a fast charge transfer at the counter electrode-electrolyte interface as a result of the higher exchange current density, in agreement with CV results. The high electrocatalytic activity of G/CNFs-Ni was attributed to its large surface area provided by beaded graphene nanosheets and good electrical conductivity brought by the incorporated $\mathrm{Ni}$ nanoparticles. Moreover, the $R_{s}$ value of the G/CNFs-Ni composite electrode was $4.23 \Omega \cdot \mathrm{cm}^{2}$, which is slightly higher than the $R_{s}$ of $3.85 \Omega \cdot \mathrm{cm}^{2}$ from the Pt electrode. These results demonstrated that the $3 \mathrm{D}$ nanostructure formed by beaded graphene nanosheets and the incorporated $\mathrm{Ni}$ nanoparticles does not suppress the diffusivity of redox species, leading to low charge-transfer and diffusion resistances in DSC devices. 


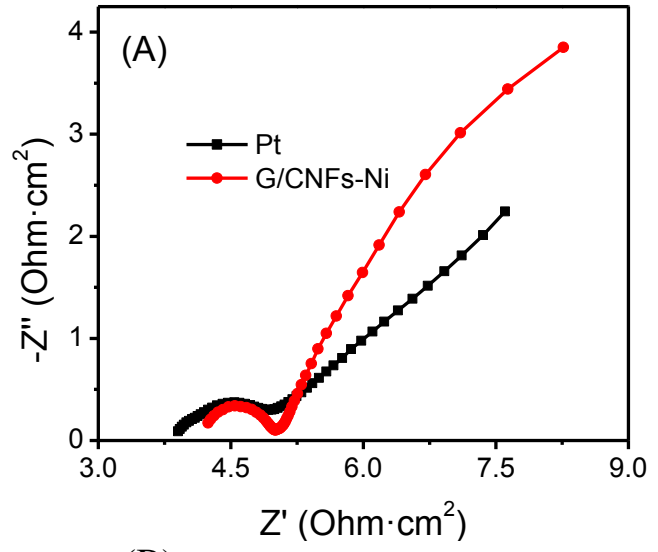

(B)

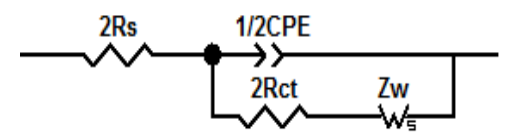

Fig. 4 (A) Nyquist plots of symmetrical dummy cells with two identical electrodes made of Pt and G/CNFs-Ni composite; (B) equivalent circuit of the photochemical cells for EIS measurement. $R_{s}$ : series resistance at the counter electrode; $R_{c t}$ : charge transfer resistance; CPE: constant phase element; and $Z_{w}$ : Nernst diffusion impedance.

Table 2. Comparison of fitted impedance parameters of the respective Pt and G/CNFs-Ni counter electrodes. The thickness of Pt and G/CNFs-Ni deposited onto FTO-glass substrate were $\sim 40 \mathrm{~nm}$ and $\sim 10 \mu \mathrm{m}$, respectively.

\begin{tabular}{ccccc}
\hline & & & & \\
\hline $\begin{array}{c}\text { Counter } \\
\text { electrode }\end{array}$ & $\mathrm{R}_{\mathrm{s}}\left(\Omega \cdot \mathrm{cm}^{2}\right)$ & $\mathrm{R}_{\mathrm{ct}}\left(\Omega \cdot \mathrm{cm}^{2}\right)$ & $\mathrm{C}\left(\mathrm{F} \mathrm{cm}^{-2}\right)$ & $\beta$ \\
\hline $\mathrm{Pt}$ & $3.85 \pm 0.07$ & $1.30 \pm 0.11$ & $2.3 \times 10^{-5}$ & 0.87 \\
\hline $\mathrm{G} / \mathrm{CNFs}-\mathrm{Ni}$ & $4.23 \pm 0.02$ & $0.72 \pm 0.04$ & $1.78 \times 10^{-4}$ & 0.89 \\
\hline
\end{tabular}

Fig. 5(A) shows the current density versus voltage $(J-V)$ curves for Pt and G/CNFs-Ni based cells under AM 1.5 illumination with a light intensity of $100 \mathrm{~mW} / \mathrm{cm}^{2}$. The photovoltaic parameters of $\mathrm{Pt}$ and G/CNFs-Ni composite based DSCs were summarized in Table 3 . The power conversion efficiencies $(\eta \%)$ of $\mathrm{Pt}$ and G/CNFs-Ni based DSCs were $7.59 \%$ and $7.14 \%$, respectively. The efficiency of the G/CNFs-Ni composite based DSC was nearly close to that of the Pt counter electrode. It is interesting to note the G/CNFs-Ni composite based DSCs have much higher efficiency than those pure $\mathrm{CNFs}^{16}$, graphene nanosheets ${ }^{11}$, C/Ni nanoparticles ${ }^{21}$. It can be concluded that the enhanced efficiency in G/CNFs-Ni composite counter electrode is due mainly to the synergetic effect of the electrospun CNFs, graphene nanosheets and Ni nanoparticles. The DSC based on Pt counter electrode had a short circuit current density $\left(J_{s c}\right)$ of 14.27 $\mathrm{mA} / \mathrm{cm}^{2}$, open circuit voltage $\left(V_{o c}\right)$ of $0.80 \mathrm{~V}$, and fill factor $(\mathrm{FF})$ of 0.66 , whereas the DSC based on G/CNFs-Ni composite exhibited $J_{s c}$ of $14.31 \mathrm{~mA} / \mathrm{cm}^{2}, V_{o c}$ of $0.84 \mathrm{~V}$, and FF of 0.60 . The G/CNFs-Ni composite based cell presented a slightly higher $J_{s c}$, and also provided an enhanced $V_{o c}$ compared to the Pt based cell. Because of the lower FF value, however, the efficiency of
G/CNFs-Ni composite based cell is lower than the expected. The relatively low FF value for the G/CNFs-Ni composite based cell is might due to the high $R_{s}$ caused by the bulk of G/CNFs-Ni composite counter electrode in cells. Nevertheless, the FF value of the G/CNFs-Ni composite based cells is still higher than those reported for pure electrospun CNFs ${ }^{14,16}$. The improved FF value can be attributed to the unique graphene-beaded carbon nanostructure and excellent electrical conductivity. Fig. 5(B) shows the incident photon-to-current conversion efficiency (IPCE) spectra of $\mathrm{Pt}$ and G/CNFs-Ni composite counter electrodes based cells. The similar values of $J_{s c}$ calculated by integrating these curves were $\sim 15 \mathrm{~mA} / \mathrm{cm}^{2}$, which are in accordance with the $J_{s c}$ values obtained from $J$ - $V$ curves.
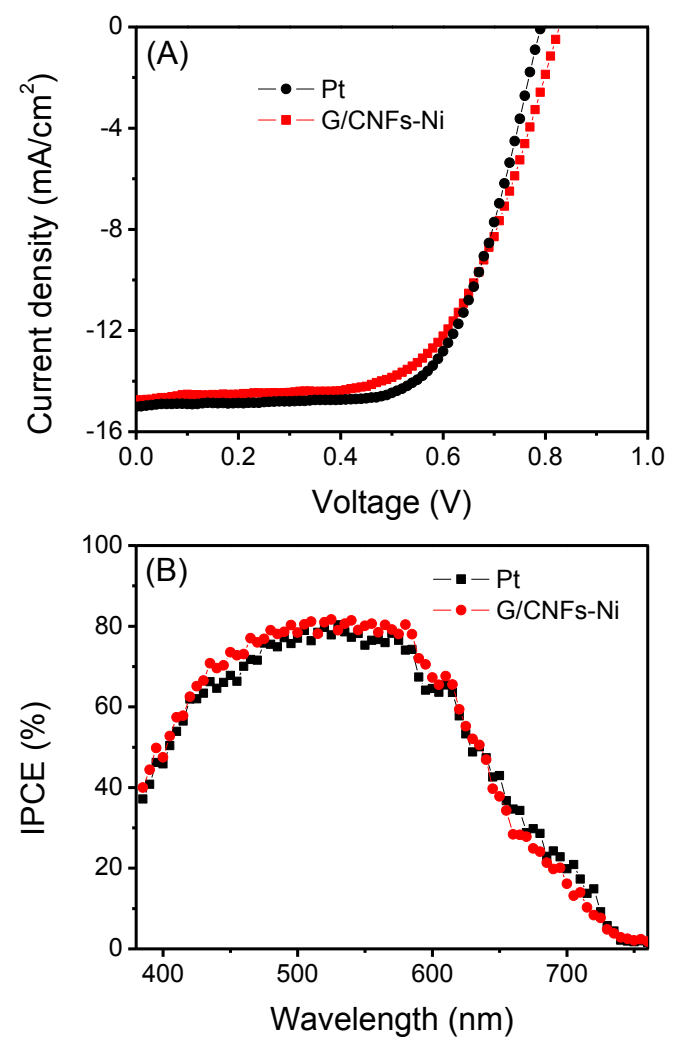

Fig. 5 (A) Current density-voltage (J-V) curves for Pt and G/CNFs-Ni composite based DSCs; (B) incident photon to current conversion efficiency (IPCE) spectrum of the DSCs based on Pt and G/CNFs-Ni composite counter electrodes.

Table 3. Comparison of photovoltaic parameters of the respective Pt and G/CNFs-Ni counter electrodes. The thickness of Pt and G/CNFs-Ni deposited onto FTO-glass substrate were $\sim 40 \mathrm{~nm}$ and $\sim 10 \mu \mathrm{m}$, respectively.

\begin{tabular}{ccccc} 
Counter electrode & $\mathrm{J}_{\mathrm{sc}}\left(\mathrm{mA} / \mathrm{cm}^{2}\right)$ & $\mathrm{V}_{\mathrm{oc}}(\mathrm{V})$ & $\mathrm{FF}$ & $\eta(\%)$ \\
\hline $\mathrm{Pt}$ & $14.27 \pm 1.07$ & $0.80 \pm 0.01$ & $0.66 \pm 0.02$ & $7.59 \pm 0.23$ \\
\hline $\mathrm{G} / \mathrm{CNFs}-\mathrm{Ni}$ & $14.31 \pm 0.62$ & $0.84 \pm 0.01$ & $0.60 \pm 0.01$ & $7.14 \pm 0.31$ \\
\hline
\end{tabular}




\section{Conclusions}

In summary, a novel porous G/CNFs-Ni composite for cost-effective counter electrode materials in DSCs was for the first time synthesized by electrospinning $\mathrm{G} / \mathrm{PAN} / \mathrm{Ni}(\mathrm{AcAc})_{2}$ precursor nanofibers, followed by carbonization and activation. The introduction of graphene nanosheets and Ni nanoparticles in CNF networks significantly increased the cells' stability, and also decreased the charge-transfer resistance at the interface between electrolyte and counter electrode, leading to the high electrocatalytic activity/efficiency for triiodide reduction. Compared to the DSCs based on Pt counter electrodes, the $J_{s c}$ and $V_{o c}$ values of the DSCs made of G/CNFs-Ni composite were slightly higher, while the FF value was slightly lower. The power conversion efficiency achieved using this novel counter electrode was $7.14 \%$ as compared to $7.59 \%$ using solution-processed $\mathrm{Pt}$ counter electrodes. This suggests that the G/CNFs-Ni composite is a promising, low-cost effective counter electrode material with similar efficiency to Pt counter electrode for the DSC application.

\section{Acknowledgements}

We acknowledge the financial support from the US-Pakistan Joint Science and Technology through National Academy of Science, NSF/EPSCoR program (grant no. 0903804) and by the State of South Dakota. X. W.is thankful to the financial support from NSF (NSF CMMI-1234297).

1. B. O'regan and M. Grätzel, nature, 353 (1991) 737-740.

2. M. Grätzel, Inorg. Chem., 44 (2005) 6841-6851.

3. S. Mathew, A. Yella, P. Gao, R. Humphry-Baker, B. F. Curchod, N. Ashari-Astani, I. Tavernelli, U. Rothlisberger, M. K. Nazeeruddin and M. Gratzel, Nat Chem, 6 (2014) 242-247.

4. P. Poudel and Q. Qiao, Nanoscale, 4 (2012) 2826-2838.

5. P. Joshi, L. Zhang, D. Davoux, Z. Zhu, D. Galipeau, H. Fong and Q. Qiao, Energy Environ. Sci., 3 (2010) 1507-1510.

6. P. Poudel, A. Thapa, H. Elbohy and Q. Qiao, Nano Energy, 5 (2014) 116-121.

7. J. Gong, J. Liang and K. Sumathy, Renewable and Sustainable Energy Reviews, 16 (2012) 5848-5860.

8. M. Ye, X. Wen, M. Wang, J. Iocozzia, N. Zhang, C. Lin and Z. Lin, Mater. Today, 18 (2015) 155-162.

9. P. Joshi, Y. Xie, M. Ropp, D. Galipeau, S. Bailey and Q. Qiao, Energy Environ. Sci., 2 (2009) 426-429.

10. X. Wang, S. Karanjit, L. Zhang, H. Fong, Q. Qiao and Z. Zhu, Appl. Phys. Lett. (2011) 082114-082114-082113.

11. J. D. Roy-Mayhew, D. J. Bozym, C. Punckt and I. A. Aksay, Acs Nano, 4 (2010) 6203-6211.

12. H. Sun, Y. Luo, Y. Zhang, D. Li, Z. Yu, K. Li and Q. Meng, J. Phys. Chem. C, 114 (2010) 11673-11679.

13. A. Aboagye, H. Elbohy, A. D. Kelkar, Q. Qiao, J. Zai, X. Qian and L. Zhang, Nano Energy, 11 (2015) 550-556.

14. P. Poudel, L. Zhang, P. Joshi, S. Venkatesan, H. Fong and Q. Qiao, Nanoscale, 4 (2012) 4726-4730.

15. P. Joshi, Z. Zhou, P. Poudel, A. Thapa, X. F. Wu and Q. Qiao, Nanoscale, 4 (2012) 5659-5664.
16. P. Joshi, L. Zhang, Q. Chen, D. Galipeau, H. Fong and Q. Qiao, ACS Appl. Mater. Interfaces, 2 (2010) 3572-3577.

17. S. H. Seo, E. J. Jeong, J. T. Han, H. C. Kang, S. I. Cha, D. Y. Lee and G.-W. Lee, ACS Appl. Mater. Interfaces, 7 (2015) 10863-10871.

18. S. Sigdel, A. Dubey, H. Elbohy, A. Aboagye, D. Galipeau, L. Zhang, H. Fong and Q. Qiao, J. Mater. Chem. A, 2 (2014) 11448.

19. Z. Zhou, X.-F. Wu and H. Fong, Appl. Phys. Lett., 100 (2012) 023115.

20. Z. Zhou, X.-F. Wu and H. Hou, RSC Advances, 4 (2014) 23622.

21. C. C. Chen, F. C. Chang, C. Y. Peng and H. P. Wang, Environ. Technol. (2014) 1-5.

22. Z. Zhou and X.-F. Wu, J. Power Sources, 222 (2013) 410-416.

23. Z. Zhou and X.-F. Wu, J. Power Sources, 262 (2014) 44-49.

24. C. Lai, Q. Guo, X. F. Wu, D. H. Reneker and H. Hou, Nanotechnology, 19 (2008) 195303.

25. M.-Y. Yen, C.-C. Teng, M.-C. Hsiao, P.-I. Liu, W.-P. Chuang, C.-C. M. Ma, C.-K. Hsieh, M.-C. Tsai and C.-H. Tsai, J. Mater. Chem., 21 (2011) 12880-12888.

26. T. N. Murakami, S. Ito, Q. Wang, M. K. Nazeeruddin, T. Bessho, I. Cesar, P. Liska, R. Humphry-Baker, P. Comte and P. Péchy, J. Electrochem. Soc., 153 (2006) A2255-A2261.

27. H. Wang, Q. Feng, F. Gong, Y. Li, G. Zhou and Z.-S. Wang, $J$. Mater. Chem. A, 1 (2013) 97-104. 
3D hierarchical graphene-beaded carbon nanofibers with incorporated Ni nanoparticles (G/CNFs-Ni) were used as counter electrode for dye-sensitized solar cells.

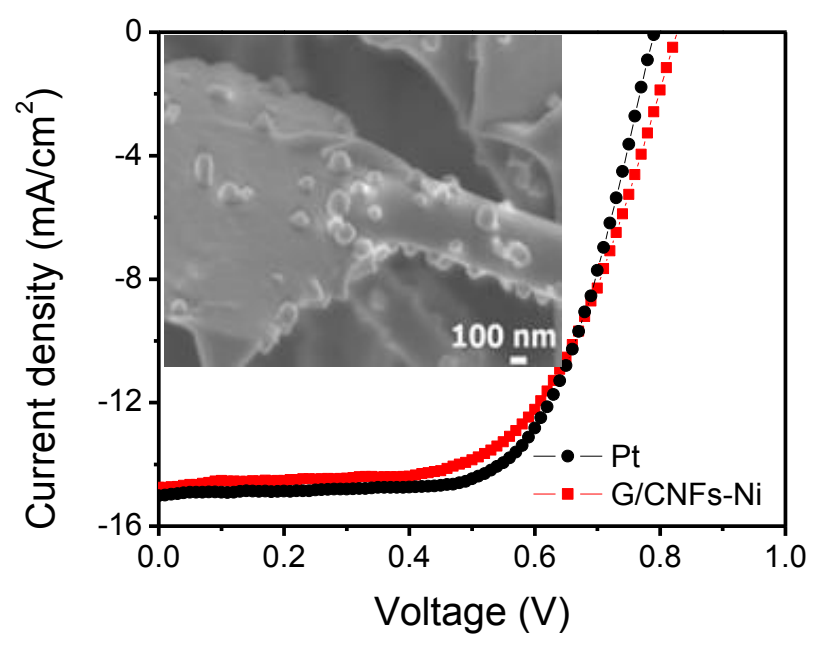

